\title{
PENERAPAN METODE BERMAIN PERAN DAN PEMBERIAN TUGAS UNTUK MENINGKATKAN PRESTASI BELAJAR BINA DIRI SISWA SLB NEGERI 2 SINGARAJA
}

\author{
I Nengah Dwi Endra Suanthara
}

STKIP Agama Hindu Singaraja, Singaraja, Indonesia e-mail: dwisuanthara@gmail.com

\begin{abstract}
Abstrak
Penelitian ini bertujuan untuk mengetahui penerapan metode bermain peran dan pemberian tugas dapat meningkatkan aktivitas dan prestasi belajar bina diri siswa SLBN 2 Singaraja. Penelitian ini didesain dengan Penelitian Tindakan Kelas yang dilaksanakan di kelas IV SLBN 2 Singaraja. Subyek penelitian adalah siswa kelas IV berjumlah 8 orang yang terdiri dari 4 laki-laki dan 4 perempuan. Metode pengumpulan data yang digunakan meliputi: wawancara dan observasi untuk mengumpulkan data tentang proses pembelajaran, sedangkan pemberian tes digunakan untuk mengumpulkan data tentang prestasi belajar bina diri. Semua data dalam penelitian ini merupakan "data experimental" artinya data yang dimapulasi melalui treatment. Metode analisis data digunakan analisis deskriptif kualitatif dengan pemaparan makna secara naratif. Temuan penelitian menunjukkan: penerapan metode bermain peran yang dipadukan dengan metode pemberian tugas dapat meningkatkan aktivitas belajar siswa dengan hasil sebagi berikut. Siklus I sebesar $44 \%$, meningkat pada siklus II sebesar $85,83 \%$. Di samping itu juga terdapat peningkatan prestasi belajar siswa yang ditunjukkan dengan nilai rerata kelas (M), daya serap (DS), dan ketuntasan belajar (KB). Peningkatan prestasi belajar tersebut dapat dilihat sebagi berikut. Siklus I: $M=66,63$; DS $=66,63 \%$ dan $\mathrm{KB}=33,33 \%$. Pada siklus II : $\mathrm{M}=85,83 ; \mathrm{DS}=85,83 \%$ dan $\mathrm{KB}=100 \%$. Jadi penerapan metode bermain peran dan pemberian tugas dapat meningkatkan aktivistas dan prestasi belajar bina diri siswa kelas IV SLBN 2 Singaraja.
\end{abstract}

Kata kunci: Bermain Peran, Tugas, Prestasi Bina diri.

\begin{abstract}
The study aims to determine the application of the role playing method and assignments can improved the activities and learning achievement of students of SLBN 2 Singaraja. This study was designed with Classroom Action Research conducted in class IV SLBN 2 Singaraja Jalan Samudra 6 Banyuasri Buleleng District. The research subjects were 8th grade students consisting of 4 men and 4 women. Data collection methods used include: interviews and observations to collect data about the learning process, while the provision of tests was used to collect data about self-development learning achievement. All data in this study were "experimental data" which were manipulation through treatment. The data analysis method used was descriptive qualitative analysis with narrative meaning exposure. The research findings showed that: the application of the role playing method combined with the method of assigning can improved student learning activities with the following results. Cycle I was $44 \%$, increased at cycle II amounted to $85.83 \%$. In addition there was also an increase in student learning achievement as indicated by the grade average (M), absorption (DS), and mastery learning $(K B)$. The improvement in learning achievement can be seen as follows. Cycle I: $M=66.63 ; D S=$ $66.63 \%$ and $K B=33.33 \%$. In cycle II: $M=85.83 ; D S=85.83 \%$ and $K B=100 \%$. So the application of the role playing method and assignments can improved the activity and learning achievement of the fourth grade students of SLBN 2 Singaraja.
\end{abstract}

Keywords : Role Playing, Task, Achievement of Self-Development 


\section{Pendahuluan}

Undang-undang Republik Indonesia No. 20 Th. 2003 tentang Sisdiknas dinyatakan bahwa, pendidikan nasional berfungsi mengembangkan kemampuan dan membentuk watak serta peradaban bangsa yang bermanfaat dalam rangka mencerdaskan kehidupan bangsa. Pendidikan bertujuan untuk berkembangnya potensi peserta didik agar menjadi manusia yang beriman dan bertaqwa kepada Tuhan Yang Maha Esa, beraklak mulia, sehat, berilmu, cakap, kreatif, mandiri, dan menjadi warga Negara yang demokratis serta bertanggung jawab. Dalam upaya merealisir tujuan tersebut, tentu peran lembaga formal dalam hal ini sekolah sangat penting. Terlebih-lebih dalam era global ini pendidikan ditantang agar mampu menghasilkan SDM yang bermutu dan sanggup berkompetisi dalam pasar kerja. Proses pembelajaran merupakan salah satu faktor penting yang harus mendapat perhatian serius dalam upaya peningkatan mutu SDM. Keberhasilan dalam mengelola proses pembelajaran sangat tergantung dari bagaimana guru menyajikan materi kepada para siswa. Pasa1 4 UU No. 20 tahun 2003, disebutkan pendidikan diselenggarakan secara demokratis, sistematis dengan sitem terbuka dan multi makna. Pendidikan diselenggarakan sebagai suatu proses pembudayaan dan pemberdayaan peserta didik.

Terkait dengan jiwa pasal 4 UU No. 20 tahun 2003, maka pengajar harus memilih dan menggunakan metode pembelajaran yang inovatif, artinya suatu cara mengajar yang mampu menciptakan suasana atau situasi baru bagi peserta didik. Situasi baru yang dimaksud adalah munculnya ide-ide baru, kreativitas baru yang tumbuh dan berkembang sebagai akibat dari proses pembelajaran yang dibangun oleh pengajar. Konsekuensi logis dari cara pembelajaran tersebut maka peserta didik akan dapat mengikuti pelajaran dan belajar secara optimal yang pada akhirnya menyelesaikan studi tepat waktu dan berprestasi tinggi.

SLBN 2 Singaraja adalah sekolah yang mengasuh anak-anak tuna grahita yaitu anak yang memiliki cacat tetap pada aspek kejiwaan yang sering disebut anak lemah mental. Anak ini adalah anak-anak di bawah normal, sehingga dipastikan mengalami masalah dalam pembelajaran. Target pembelajaran yang diterapkan pasti tidak sama dengan target untuk anak-anak normal. Salah satu aspek pembelajaran yang perlu mendapat perhatian bagi guru adalah pembelajaran "Bina Diri". Pembelajaran ini memberi kontribusi yang sangat penting untuk masa depan anak. Bina diri merupakan suatu proses pembelajaran yang menekankan pengembangan sikap, mental, tatalaksana, perilaku berdasarkan norma/moral agama melalui pengembangan kemampuan dan keterampilan terhadap diri sendiri maupun lingkungan. Tujuannya antara lain agar anak dapat mengurus dirinya sendiri dalam kehidupan sosial di masysrakat, menanamkan sikap percaya pada diri sendiri, mengurangi sikap ketergantungan dan menanamkan sikap disiplin dan kerja sama.

Fenomena yang muncul di SLBN 2 Singaraja terkait dengan mata pelajaran "Bina Diri" ditemukan beberapa permasalahan yaitu: pembelajaran rendah atau anak pasif, hanya melihat guru mengajar dan tidak melakukan kegiatan pembelajaran. Fakta ini diperkuat dari hasil wawncara kepada guru kelas yang mengajar di kelas IV, dijelaskan bahwa, siswa memang tidak perhatian terhadap materi pelajaran, tampak tidak ada minat dengan materi pelajaran, situasi pasif. Disamping aktivitas rendah, juga prestasi belajar mata pelajaran "Bina Diri" rendah. Fakta pendukung prestasi anak rendah dapat dilihat dan hasil pre-test yang diberikan sebelum pemberian tindakan diperoleh: nilai rata-rata kelas sebesar 62,0 daya serap $62 \%$ dan ketuntasan belajar sebesar $0 \%$. Semua siswa memperoleh nilai di bawah rata-rata kelalasnya.

Permasalahan di atas, mungkin dapat disebabkan oleh beberapa faktor sebagai berikut. 1) Dalam pembelajaran, guru kurang menuntut kesiapan belajar siswa, guru hanya mengajar dengan menggunakan metode caramah, dan tidak memperhatikan apakah anak sudah dapat menerima materi pelajaran atau belum. 2) Sebagian besar proses pembelajaran (90\%) guru menggunakan metode konvensional (ceramah), tanpa mengkombinasikan dengan metode lain. 3). Guru dalam proses pembelajaran hanya berusaha menuntaskan materi pelajaran ketimbang memperhitungkan ketuntasan belajar siswa. 4). Proses pembelajan tidak memberi tantangan kepada siswa untuk mengerjakan sesuatu, karena guru tidak memberikan target pencapaian. Hal ini menyebabkan siswa tidak 
membuat persiapan belajar di rumah untuk keesokan harinya. 5). Motivasi kerja siswa untuk melatih diri sangat rendah. 6). Sistem penilaian guru dalam menilai hasil belajar siswa masih konvensional yaitu menilai dengan mengukur kognitif dengan memberikan tes. Pembelajaran seperti ini sangat tidak cocok untuk anak-anak SLBN 2 Singaraja karena anak tidak mampu memahami konsep atau teori.

Kondisi tersebut di atas merupakan masalah yang penting dan harus dicarikan pemecahannya. Sebagai upaya pemecahan masalah di atas digunakan penerapan metode bermain peran dan pemberian tugas. Penerapan metode ini nantinya diharapkan dapat meningkatkan aktivitas pembelajaran dan prestasi belajar "Bina Diri". Tujuan penelitian ini adalah untuk mengetahui penerapan metode bermain peran dan pemberian tugas dapat meningkatkan aktivitas dan prestasi belajar siswa. Sedangkan manfaat terhadap hasil penelitian dimana siswa memperoleh dan dapat mengalami proses pembelajaran yang lebih komunikatif, mereka aktif mengerjakan tugas dengan suasana senang riang gembira. Bagi guru; model pembelajaran ini merupakan model baru yang inovatif dan dapat digunakan sebagai acuan dalam mengajar untuk dapat mencapai target pembelajaran yang lebih efektif dan efesien.

Kajian teori yang dibangun merupakan kajian kritis yang didasarkan pada pertimbangan logika dan relevansi terhadap variabel penelitian. Beberapa teori relevan meliputi: Moedjiono, dkk. (1992:67), Djajadisastra (1985:26), (http://gunipkn.wordpress.com/2007/11/16/metode-role-playing/) dinyatakan bahwa cara mengajar dengan mengemas materi dalam bentuk permainan dan tugas dimana anak dapat belajar, mengerjakan tugas sambil bermain. Cara ini dapat menumbuhkan rasa senang, tidak bosan serta berfungsi mengembangkan sikap sosial dan melatih tanggung jawab anak. Aktivitas belajar tumbuh secara alami dan prestasi belajar dapat meningkat. Sadiman (dalam Agus, 2006 : 3), pengetahuan (Nurkancana dan Sunartana, 1992:3), Raka Joni (dalam Dharmayanti 2007:9) dinyatakan bahwa prestasi belajar siswa merupakan peningkatan kemampuan siswa dalam belajar mengajar yang juga menunjukkan keberhasilan guru dalam menyampaikan informasi dan pesan kepada siswa. Prestasi belajar siswa juga berarti prestasi guru. Prestasi belajar menunjukkan adanya peningkatan dalam proses pembelajaran. Prestasi belajar adalah kemampuan aktual yang berbentuk nilai atau skor siswa. Nilai atau skor siswa merupakan respon verbal yang diperoleh melalui tes hasil belajar yang dilaksanakan setelah proses perlakuan dilaksanakan.

Bina diri merupakan suatu proses pembelajaran yang menekankan pada pengembangan kepribadian melalui pengembangan kemampuan dan keterampilan terhadap diri sendiri maupun sosial (Kurikulum Pendidikan Luar Biasa, 1997). Metode pembelajaran adalah suatu cara yang digunakan oleh seorang guru dalam menyampaikan materi pembelajaran kepada peserta didik. Metode dapat mempermudah pemahaman materi, dapat membuat suasana lebih menarik, dapat menumbuhkan motivasi dan aktivitas belajar. Guru dapat menggunakan metode pembelajaran sesuai dengan tujuan pembelajaran, materi, pengalaman / kemampuan serta sarana dan prasarana yang tersedia. Ini berarti guru dapat menggunakan metode pembelajaran lebih dari satu jenis atau mengkombinasikan beberapa metode dalam satu proses pembelajaran. Metode bermain peran yang dikombinasikan dengan pemberian tugas merupakan cara menyajikan materi pembelajaran dimana materi tersebut dikemas dalam bentuk tema-tema tertentu dan dari masing-masing tema tersebut dibuat serangkaian tugas. Kemudian tugas tersebut diimplementasikan dalam suatu peran tertentu, peserta didik mengerjakan tugas tersebut. Tugas yang disusun secara sistematis dan jelas, akan lebih mudah untuk dipahami, melalui permainan peran sehingga peserta didik dapat mengerjakan dengan mudah juga. Tugas disusun secara sistematis disesuaikan dengan kondisi anak sehingga akan dapat memotivasi anak untuk mengikuti proses pembelajaran dengan senang. Tugas disusun berdasarkan materi yang diajarkan melalui pemanfaatan model atau peran tertentu. Peran yang dipilih adalah peran yang sudah biasa dikenal oleh siswa. Guru membimbing berperan aktif dalam memberi tuntunan agar semua siswa dapat mengerjakan atau memainkan peran secara tepat dan benar. Siswa mengerjakan tugas secara individual dan kelompok. Guru memperhatikan agar semua siswa dapat mengambil peran sesuai tujuan yang diinginkan. Bila tuntunan terhadap tugas melalui 
bermain peran dilaksanakan secara mantap, tekun dan menyenangkan bagi siswa diduga dapat meningkatkan aktivitas dan prestasi belajar siswa dalam mata pelajaran bina diri.

\section{Metode}

Penelitian ini didesain dalam penelitian tindakan kelas (classroom action research) bertujuan untuk meningkatkan aktivitas dan prestasi belajar bina diri di SLBN 2 Singaraja. Tempat penelitian berlokasi di SLBN 2 Singaraja dengan subyek penelitian sebanyak 8 orang dengan rincian: 4 orang laki-laki dan 4 orang perempuan. Prosedur pelaksanaan penelitian tindakan kelas merupakan proses yang dinamis, dengan empat tahap yaitu: a) perencanaan tindakan, b) pelaksanaan tindakan, c) observasi, evaluasi dan analisis, dan d) refleksi. Metode pengumpulan data yang digunakan meliputi: wawancara, observasi dan testing. Sedangkan analisis data digunakan analisis deskriptif kualitatif dengan bantuan statistik dasar untuk mencari: rata-rata kelas, daya serap dan ketuntasan belajar.

Target penelitian adalah indikator yang ditetapkan sebagai dasar untuk menentukan keberhasilan minimal dari suatu penelitian. Apabila indikator keberhasilan minimal telah tercapai pada siklus tertentu maka pelaksanaan siklus tersebut dihentikan karena telah dinyatakan berhasil. Secara rinci indikator keberhasilan minimal penelitian ini seperti tabel di bawah ini.

Dalam penelitian tindakan kelas (PTK) ini mengacu pada teori yang dikemukakan Stephen Kemmis dan Robin McTaggrat (dalam Agung, 2005:91). Dalam model PTK ini ada 4 tahapan yaitu: perencanaan, pelaksanaan, observasi dan refleksi. Pelaksanaan penelitian dapat digambarkan dalam model seperti gambar berikut.

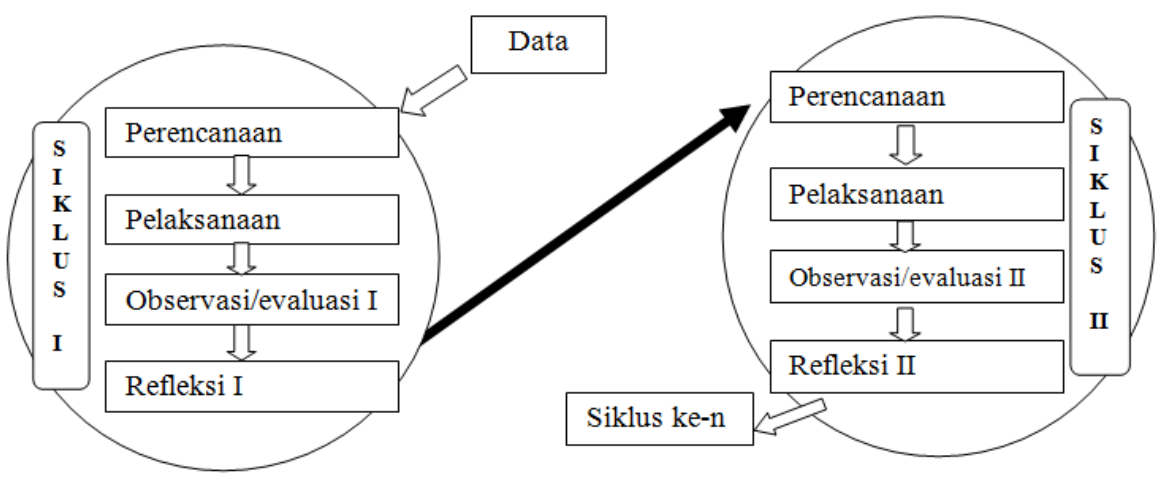

Gambar 1. Model Penelitian Tindakan Kelas Stephen Kemmis dan Robin MacTaggart (di modifikasi oleh Sukardi, 2008)

1) Siklus I

Adapun tahapan Siklus I terdiri dari rencana tindakan, pelaksanaan, pengamatan/ evaluasi dan refleksi, Siklus 1 dilaksanakan selama 4 kali pertemuan yaitu 3 kali untuk pelaksanaan pembelajaran dan 1 kali pertemuan untuk pelaksanaan tes yang akan dipaparkan sebagai berikut.

a. Tahap perencanaan

Adalah perencanaan yang dilakukan untuk memperbaiki dan meningkatkan proses pembelajaran. Pada tahap ini peneliti dan guru pengampu mata pelajaran saling membantu dalam upaya memperbaiki dan meningkatkan prose pembelajaran menjadi lebih baik. Adapun kegiatan yang dilakukan pada rancangan tindakan ini adalah: (1) menyiapkan materi yang akan diajarkan dengan berkonsultasi kepada guru pengampu mata pelajaran, (2) menyusun rencana pelaksanaan pembelajaran (RPP) sesuai dengan model dan metode serta materi pembelajaran, (3) menyiapkan media pembelajaran, (4) menyiapkan instrument penilaian/tes dan lembar observasi.

b. Tahap Pelaksanaan Tindakan 
Pelaksanaan tindakan dilakukan sesuai dengan scenario pembelajaran yang telah dirancang. Fase ini diawali dengan melaksanakan pembelajaran Matematika dengan menggunakan model Pembelajaran Kuantum. Pembelajaran yang dilaksanakan sesuai dengan RPP yang telah dirancang. Adapun tahapan-tahapan pelaksanaan pembelajaran siklus I yaitu,

1) Siswa mencari permasalahan yang berkaitan dengan topik pembelajaran.

2) Siswa mencari strategi pemecahan masalah yang telah mereka temukan

3) Pengajuan penjelasan dan solusi terhadap permasalahan

4) Fase tindak lanjut yaitu berupa tindakan aplikasi personal dan social

c. Tahap Observasi/Evaluasi

Observasi/Evaluasi dilakukan untuk mengetahui kegiatan yang dilakukan oleh guru dan siswa dalam proses pembelajaran. Observasi/Evaluasi ini perlu dilakukan untuk mengetahui kesesuaian antara perencanaan dan pelaksanaan tindakan setiap siklus.

d. Refleksi

Refleksi ini dilakukan untuk mengkaji hasil tindakan siklus I mengenai motivasi dan hasil belajar. Tujuan refleksi adalah untuk membangun kekuatan-kekuatan yang ditemukan, kelemahan-kelamahan, dan hambatan-hambatan yang dialami dalam mencapai tujuan yang diharapkan. Hasil refleksi ini digunakan sebagai dasar atau acuan untuk menyempurnakan tahapan-tahapan penelitian pada siklus selanjutnya. Pelaksanaan tindakan akan dihentikan apabila hasil evaluasi telah menunjukkan hasil yang ingin dicapai.

\section{2) Siklus II}

Tahapan Siklus II terdiri dari rencana tindakan, pelaksanaan, pengamatan/evaluasi dan refleksi. Siklus II dilaksanakan selama 4 kali pertemuan yaitu 3 kali untuk pelaksanaan pembelajaran dan 1 kali pertemuan untuk pelaksanaan tes. Pelaksanaa siklus II hampir sama dengan siklus I, namun pada siklus II lebih menekan pada perbaikan kesalahankesalahan yang terjadi pada siklus I.

Untuk mengumpulkan data digunakan metode tes prestasi belajar kepada siswa, kemudian untuk menganalisis data hasil penelitian menggunakan metode deskriptif. Untuk data kuantitatif dianalisis dengan mencari mean, median, modus, membuat interval kelas dan melakukan penyajian dalam bentuk tabel dan grafik. Tingkat keberhasilan target pencapaian untuk menandakan akhir penelitian yaitu apabila siswa mencapai nilai rata-rata 70 dan dengan presentase ketuntasan belajar minimal mencapai $80 \%$.

\section{Hasil dan Pembahasan}

Berdasarkan hasil analisis diperoleh bahwa penelitian tindakan kelas ini terdiri dua siklus karena pada siklus ke dua indikator keberhasilan telah terpenuhi dengan hasil sebagai berikut.

Tabel 01. Hasil Penekitian Siklus I dan Siklus II

\begin{tabular}{lllll}
\hline No & Siklus I & & Siklus II & Target \\
\hline 1. & Aktivitas & $: 44 \%$ & $83,33 \%$ & Terpenuhi \\
& Rata-rata & $: 66,63$ & 85,83 & Terpenuhi \\
& Daya Serap & $: 66,63 \%$ & $85,83 \%$ & Terpenuhi \\
& Ketuntasan Bel & $: 33,33 \%$ & $100 \%$ & Terpenuhi \\
\hline
\end{tabular}

Berdasarkan tabel 01 di atas dapat dijelaskan bahwa hasil penelitian menunjukkan penerapan metode bermain peran dan pemberian tugas dapat meningkatkan aktivitas dan prestasi belajar bina diri. Hal ini ditunjukkan dengan peningkatan aktivitas belajar dari sklus I, ke siklus II, yaitu: $44 \%$ menjadi $83,33 \%$. Prestasi belajar bina diri juga meningkat dari siklus I, ke siklus II, yaitu: Siklus I: rata-rata kelas $(M)=66,63$, daya serap $(D S)=66,63 \%$ dan 
ketuntasan belajar $(K B)=33,33 \%$. Sklus II: rata-rata $(M)=85,83$, daya serap $(D S)=85,83 \%$, ketuntasan belajar (KB) kelasikal $=100 \%$. Peningkatan hasil belajar terjadi karena penerapan metode bermain peran dan pemberian tugas diterapkan secara tepat dan benar. Hasil penelitian tersebut ternyata sesuai dengan teori yang diunggah secara online (http://gurupkn.wordpress.com/metode-role-playing/), Surakhmad (1986), Djamarah, dkk, (2002), Moedjiono, dkk. (1992) menekankan bahwa, metode bermain peran dan pemberian tugas merupakan suatu cara yang fungsinya sebagai alat untuk mencapai tujuan pembelajaran berupa penciptaan aktivitas belajar yang kondusip dan peningkatan prestasi belajar. Hasil penelitian ini juga sejalan dengan pendapat Djajadisastra (1985), Sumantri, dkk. (1999) ditekankan bahwa, bermain dan tugas dapat menarik minat, melatih tanggung jawab, membuat siswa aktif, memelihara hubungan baik antara guru dengan siswa. Hasil penelitian ini juga relevan dengan temuan para ahli sebelumnya yaitu: Depdiknas (2000), Puspa (1997), Artawan (2002) dimana ditegaskan bahwa, metode pembelajaran yang digunakan guru seperti bermain peran, tugas, diskusi, dan lain-lain dapat meningkatkan aktivitas dan prestasi belajar siswa. Metode ini didesain dengan mengubah paradigma pembelajaran yang konvensional yang bersifat "teacher oriented / teacher dominated learning" ke situasi yang lebih kondusif yaitu "students centered students dominated learning" atau bersifat horizontal yang melibatkan murid dalam proses kegiatan mental melalui bermain dan tugas yang dituntun menggunakan pendekatan klinis.

Keberhasilan di atas banyak dipengaruhi oleh terciptanya suatu kondisi yang kondusip dimana siswa merasa senang / gembira / tidak takut/ tidak kaku dalam mengikuti proses pembelajaran sekalipun mereka berhadapan pada materi pelajaran yang baru. Dalam proses belajar mereka tidak ragu-ragu untuk bertanya kepada temannya ataupun kepada gurunya. Bermain peran dan pemberian tugas juga sangat efektif untuk menumbuhkan motivasi belajar. Tumbuhnya kesadaran siswa bahwa "belajar sukses identik dengan kesalahan" ternyata efektif mendorong mereka untuk mencoba melakukan, melatih diri, menemukan sebanyak-banyaknya dan tidak takut terhadap apakah yang mereka lakukan benar atau salah. Semua hal tersebut di atas bermuara dari penerapan metode pembelajaran bermain peran dan pemberian tugas secara konsekuen dan mantap.

\section{Simpulan dan Saran}

\section{Simpulan}

Penerapan metode pembelajaran berrnain peran dan pemberian tugas temyata dapat meningkatkan aktivitas dan prestasi belajar bina diri siswa. Metode ini dapat menumbuhkan suasana belajar yang lebih akrab, menyenangkan dan dapat melatih sikap mandiri dan tanggung jawab serta menumbuhkan sikap sosial anak. Terkait dengan hasil di atas implikasi bahwa pembelajaran ini lebih menekankan pada aspek pembinaan karakter sehingga guru harus mampu menjadi model yang ditiru oleh anak selama proses pembelajaran berlangsung. Proses meningkatkan aktivitas dan prestasi belajar bina diri terjadi secara alami. Implikasi terhadap guru khususnya di lingkungan SLBN 2 Singaraja, adalah menggunakan metode pembelajaran bermain peran dan pemberian tugas ini sebagai model pembelajaran inovatif untuk semua mata pelajaran khususnya pelajaran. Penerapan metode ini membutuhkan kerja keras baik dari guru pengajar maupun siswa yang belajar.

\section{Saran}

Berdasarkan kesimpulan di atas dapat disampikan saran yaitu 1) Siswa hendaknya dapat berperan aktif dengan menyampaikan ide atau pemikiran pada proses pembelajaran, sehingga proses pembelajaran dapat berjalan dengan lancar sehingga memperoleh prestasi belajar yang optimal.; 2) Untuk meningkatkan prestasi belajar diharapkan menggunakan model pembelajaran Kuantum. Untuk meningkatkan keaktifan, kreativitas siswa dan keefektivan pembelajaran diharapkan menerapkan metode bermain peran. Untuk memperoleh jawaban yang tepat, sesuai dengan tujuan penelitian disarankan untuk menggali pendapat atau tanggapan siswa dengan kalimat yang lebih mengarah pada proses 
pembelajaran dengan metode bermain peran; 3) Bagi peneliti lain diharapkan lebih mempersiapkan diri dalam proses pengambilan dan pengumpulan dan segala sesuatunya sehingga penelitian dapat dilaksanakan dengan lebih baik. Peneliti selanjutnya diharapkan ditunjang pula dengan wawancara dengan sumber yang kompeten dalam kajian sarana prasarana pendidikan dan efektivitas proses pembelajaran.

\section{Daftar Pustaka}

Ahmad, DS. (2000). Kemampuan Merawat Diri. Jakarta: Departemen Pendidikan dan Kebudayaan.

Alit Emran, dkk.(tt). Strategi BelajarMengajar PMP Berdasarkan Prinsip CBSA. Jakarta : Depdikbud.

Arikunto S, (1992). Prosedur Penelitian Suatu Pendekalan Praktis. Jakarta : Rineka Cipta.

Badan Pembinaan Pendidikan Pelaksanaan Pedoman Penghayatan Dan Pengamalan Pancasila. BP. 7 Pusat. 1996. Jakarta : Petunjuk Pelaksanaan Simulasi P4.

Departemen Pendidikan dan Kebudayaan. (1997). Kurikulum Pendidikan Luar Biasa.

Direktorat Jenderal Pendidikan Dasar Dan Menengah. Departemen Pendidikan Dan Kebudayaan Republik Indonesia. 1984. Jakarta: Pedoman Metode Penyajian PMP Dan Penerapannya Untuk Guru Sekolah Dasar.

Dharmayanti. (2006). Peningkatan Kreativitas Dan Prestasi Belajar Melalui Metode Permainan Pada Pembelajaran Matematika Di Kelas I SDN 2 Sudaji. Tidak Diterbitkan. Singaraja: Program Studi S1 PGSD Fakultas IImu Pendidikan Universitas Terbuka.

Djamarah, dkk. (2002) Strategi Belajar Mengajar. Jakarta : Reneka Cipta.

http://gurupkn.wordpress.com/2007/11/16/metode-role-playing/. Metode Bermain Peran. Artikel ini tentang permainan yang dilakukan dengan memainkan peran sebuah karakter.

Hedi Suparma. (1997). Penerapan Metode Simulasi Dapat Meningkatkan Kreativitas Dan Prestasi Belqjar Siswa Dalam Pembelajaran PPKN Di Kelas IV B SLTPN, 3 Gerokgak. Sekripsi (tidak diterbitkan). Singaraja : Perpustakaan IKIPN. Singaraja.

Sudiasa. (2997). Penerapan Metode Simulasi Dalam Upaya Meningkatkan Prestasi Belajar Siswa Pada Mata Pelajaran PPKN Di Kelas IV.3 SARA Pupuan. Ttidak Diterbitkan. Singaraja : Perpustakaan IKIPN Singaraja. 